\title{
Health-related quality of life of teen/adult patients with cystic fibrosis in the Republic of North Macedonia
}

\author{
Zoran Nakov ${ }^{1^{*}}$, Stevche Acevski ${ }^{2}$, Valentina Velkoska ${ }^{3}$, Stojka Naceva Fushtik ${ }^{4}$, \\ Natalija Nakov ${ }^{5}$, Jasmina Tonikj Ribarska ${ }^{5}$, Suzana Trajkovikj Jolevska ${ }^{5}$ \\ ${ }^{1}$ Novo Nordisk Pharma DOOEL, \\ blvd. Oktomvriska Revolucija 18, 1000 Skopje, R.N. Macedonia \\ ${ }^{2}$ Roche Makedonija DOOEL, str. Cyril and Methodius 7, 1000 Skopje, R.N. Macedonia \\ ${ }^{3}$ Faculty of Medicine, University "Goce Delchev" Shtip, \\ str. Ljuben Ivanov 25, 2000 Shtip, R.N. Macedonia \\ ${ }^{4}$ University clinic for children diseases, Ss. Cyril and Methodius University in Skopje, \\ str. Mother Tereza 47, 1000 Skopje, R.N. Macedonia \\ ${ }^{5}$ Faculty of Pharmacy, Ss. Cyril and Methodius University in Skopje, \\ str. Mother Tereza 47, 1000 Skopje, R.N. Macedonia
}

Received: May 2021; Accepted: June 2021

\begin{abstract}
The present study investigates the Health-related quality of life of teen/adults patients with cystic fibrosis in the Republic of N. Macedonia for the first time. The main objective was to describe the health-related quality of life status of these patients with cystic fibrosis and the second objective was to investigate the connection of the current medical treatment with the analysed parameters.

The survey was conducted on 31 patients by using the Cystic Fibrosis Questionnaire Revised for Health-related quality of live measurement and questions for current medical treatment.

All patients scored their digestive condition with the highest score, while the lower score was reported for social activity. The gender, the nationality and the educational level of the patients with Cystic Fibrosis had no significant impact on their perception of Health-Related Quality of Live.

The highest score for digestive condition was in positive correlation with the fact that all patients continuously used enzyme therapy. Patients who practiced physical therapy and physical activities reported high scores for physical conditions and body images. This finding point out that patient with Cystic Fibrosis should be encouraged to practice physical activity more often.

The lowest scores for life activities and treatment burden shows that this medical condition has a negative impact on the patients' self-perception and in the execution of their daily activities.
\end{abstract}

Keywords: cystic fibrosis, Health-Related Quality of Live, digest, daily activities

\section{Introduction}

Cystic fibrosis $(\mathrm{CF})$ is genetic disorder, the most common inherited disease in the white population, with autosomal recessive manner of inheritance (Tsui and
Buchwald, 1991). The incidence of CF in the white population is about 1:2500 live births (Bobadilla et al., 2002). As a genetic disorder, CF affects mostly the lungs, but it also affects the pancreas, liver, kidneys and intestine too. The disease is characterized by different expression and at different rates of progression in

\footnotetext{
*z_nakov@yahoo.com
} 
different organs (www.cff.org). The clinical picture is dominated by symptoms of impaired functioning of the respiratory and intestinal tract (Naceva Fushtikj, 2012).

The median survival of $\mathrm{CF}$ patients has doubled since 1969 to 1990 from 14 to 28 years and in 2007 it was 37.4 years (Fitz Simmons, 1993; Zemanick et al., 2010). It is estimated that children born in the last decade, using the current standards of treatment in specialized centers for $\mathrm{CF}$, could live for 40-45 years, even without further treatment progression (Elborn, 1993; Lewis et al., 2007). According to available data in 33 EU countries, more than 42000 patients with CF have been registered (www.ecfs.eu). In Republic of North Macedonia a total of 112 patients with CF have been registered at the beginning of 2017 (www.cf.mk).

The treatment of the Macedonian teen/adults patients with CF is carried out at the Centre for Cystic Fibrosis, which is an integral part of the University Clinic for Children's Diseases - Skopje. This centre is also part of the Register of patients with cystic fibrosis at EU level the European Cystic Fibrosis Society Patient Registry (ECFSPR). The Centre for Cystic Fibrosis makes efforts related to the implementation of the European consensus on standards of care for patients with CF (Kerem et al., 2005).

Health-related quality of life (HRQoL) is a parameter that is examined in the area of clinical effectiveness. HRQoL can be defined as a patient's general subjective perception of the effect of illness and intervention on physical, psychological and social aspects of daily life (www.ispor.org/workpaper/emea-hrql-guidance.pdf5; www.fda.gov/downloads/drugs/ guidances/ucm193282.pdf 2009).

Physical functioning refers to mobility, self-care, usual activities and other functional abilities. Psychological health includes elements like cognitive functioning, emotional distress and anxiety. Finally, social health refers to the quantity and quality of social contacts and interactions (Goodman, 1998). A single domain, e.g. physical functioning, is insufficient to cover HRQoL, even though it is an endpoint relevant to patients (Jackowski and Guyatt, 2003).

The measurement of HRQoL is particularly important in chronic diseases where an assessment of the impact of the intervention should be made in order to improve the functional capabilities of the patients. HRQoL measurements could be conducted using generic HRQoL instruments, disease-specific HRQoL instruments or population-specific HRQoL instruments

(www.eunethta.eu).

In Republic of North Macedonia, the HRQoL survey of patients with CF has not been conducted before. The main goal of this survey was to describe the current health status of patients with CF in R. of North Macedonia. The second goal was to investigate the connection of the current medical treatment with the HRQoL parameters. This study covered adult patients with different ethnic backgrounds.

\section{Material and methods}

The participants included in this research were adolescents and adult patients ( $\geq 14$ years of age). The treatment is carried out at the Center for Cystic Fibrosis, University Clinic for Children's Diseases - Skopje.

The survey of the patients was conducted by using the available Macedonian version of Cystic Fibrosis Questionnaire Revised (CFQ-R) as a disease-specific HRQoL instrument. (Henry et al., 2017). Previously, consent to use this questionnaire was provided. Additional questions for current medical treatment/therapy were prepared by the physician (Macedonian national leader for treatment of $\mathrm{CF}$ ), who is responsible for the medical treatment of these patients.

The questions given in this diseases-specific HRQoL instrument covered three modules: HRQoL, symptoms and overall health perception

The CFQ-R Adults cover eight domains from HRQoL module (Physical Functioning, Vitality, Emotional state, Social limitations, Role Limitations/School Performance, Body Image, Eating Disturbances, Treatment burden), three domains from symptoms module (Respiratory, Digestive and Weight) and one domain from health perception scale (Health Status, present/evolution).

The survey was conducted for a period of nine months. The questionnaires were administrated as a selfadministered. CFQ-R questionnaires were distributed during the regular control process of patients and after their fill at home, patients were asked to return the questionnaires at the next control.

In total 31 patients were cover with these CFQ-R Teen/Adults questionnaire. All involved patients were informed about the study objectives and data confidentiality, and were asked to indicate their agreement to participate.

The answers of the questions from HRQoL module were given as a 5 distinct 4-point Likert scales (always/often/sometime/never). The score was ranged between 0 to 100 , whereas higher scores representing a better health.

The statistical analysis was performed using SPSS statistical software (available with the questionnaire, SPSS statistical software), Student t-test for independent samples, Mann-Whitney nonparametric test, Analysis of Variance-post hoc Tukey test, Kruskal-Wallis ANOVApost hoc Mann-Whitney test, Pearson test and Spearman test.

\section{Results}

Thirty-one patients (adults and adolescents) were involved in HRQoL survey and 12 domains (HRQoL, symptoms and health status) were analyzed. Among them there were 20 men and boys $(64.52 \%)$ and 11 women and 
Table 1. The socio-demographic profile of these patients

\begin{tabular}{|c|c|}
\hline \multicolumn{2}{|c|}{ Gender } \\
\hline Male & $20(64.52 \%)$ \\
\hline Female & $11(35.48 \%)$ \\
\hline \multicolumn{2}{|c|}{ Age } \\
\hline $38-47$ & $2(6.45 \%)$ \\
\hline $27-37$ & $7(22.58 \%)$ \\
\hline $17-26$ & $10(32.26 \%)$ \\
\hline $14-16$ & $12(38.71 \%)$ \\
\hline \multicolumn{2}{|c|}{ Nationality } \\
\hline Ethnic Macedonians & $23(74.19 \%)$ \\
\hline Ethnic Albanians & $5(16.13 \%)$ \\
\hline Other & $1(3.23 \%)$ \\
\hline I prefer not to response & $2(6.45 \%)$ \\
\hline \multicolumn{2}{|c|}{ Level of education } \\
\hline Primary education & $9(29.03 \%)$ \\
\hline Part of secondary education & $4(12.9 \%)$ \\
\hline Secondary education & $11(35.48 \%)$ \\
\hline High education & $7(22.58 \&)$ \\
\hline
\end{tabular}

girls $(35.48 \%)$. The ethnic structure of the patients was dominated by ethnic Macedonians. According to the level of education, the most prevalent were patients with completed secondary school.

The socio-demographic profile (gender, age, nationality and level of education) of all included teen/adults patients with CF patients is presented in Table 1.

The descriptive parameters for all 12 domains are presented in Table 2. All patients (adults and adolescents) scored their digestive condition with the highest score (mean 87.81 \pm 16.6 ; med 100; IQR 22.2), while the lower score was reported for social activity (mean $49.64 \pm 8.6$; med 50; IQR 11.1).

The male patients scored their physical condition $(p=0.39)$, vitality $(p=0.9)$, social activity $(p=0.43)$ and role $(p=0.66)$ not significantly higher compared to female patients. The female patients scored higher their emotional condition $(p=0.55)$, eating $(p=0.77)$, treatment burden $(p=0.98)$, health perception $(p=0.64)$, body image $(p=0.39)$, weight $(p=0.84)$ and respiratory function $(p=0.41)$, but these differences were not significant. The identical scores, from male and female patients, were given for their digestive condition (Table 3).

The results showed that there were not statistical significantly difference in HRQoL perception between Albanian and Macedonian patients with CF (Table 4).

The education level of the patients with $\mathrm{CF}$ has no statistically significant influence on the self-perception of physical condition $(p=0.355)$, vitality $(p=0.71)$, emotional condition $(p=0.45)$, eating $(p=0.79)$, treatment burden $(p=0.26)$, health perception $(p=0.5)$, social activity $(p=0.24)$, body image $(p=0.44)$, role $(p=0.92)$, weight $(p=0.79)$ and respiratory function $(p=0.38)$. The education level was found significant only for the perception of the digestive condition as a part of HRQoL $(p=0.012)$ (Table 5).

Table 2. Descriptive parameters for analyses of HRQoL domains

\begin{tabular}{lcccc}
\hline \hline Variable & $\mathrm{N}$ & Mean $\pm \mathrm{SD}$ & Median $(\mathrm{IQR})$ & $\min -\max$ \\
\hline Physical & 31 & $73.52 \pm 18.3$ & $75.0(33.33)$ & \multirow{2}{*}{$33.3-100$} \\
Vitality & 31 & $68.01 \pm 19.0$ & & \\
Emotion & 31 & $74.19 \pm 20.9$ & $80.0(33.33)$ & \\
Eating & 31 & $79.93 \pm 20.2$ & $88.89(33.33)$ & \\
Treatment Burden & 31 & $59.86 \pm 21.6$ & $66.67(33.33)$ & \\
Health Perceptions & 31 & $70.25 \pm 21.2$ & & $11.11-100$ \\
Social & 31 & $49.64 \pm 8.6$ & $50.0(11.11)$ & \\
Body Image & 31 & $77.42 \pm 22.9$ & $77.78(44.4)$ & \\
Role & 31 & $78.76 \pm 18.4$ & $83.33(25)$ & \\
Weight & 31 & $80.64 \pm 29.5$ & $100.0(33.33)$ & $33.33-94.44$ \\
Respiratory & 31 & $73.65 \pm 15.3$ & & \\
Digest & 31 & $87.81 \pm 16.6$ & $100.0(22.22)$ & \\
\hline
\end{tabular}

Standard deviation (SD), Interquartile range (IQR), Number of patients (N), no statistical significance (ns)

Макед. фарм. билт., 67 (1) 33 - 41 (2021) 
Table 3. Descriptive statistics for all analyzed HRQoL domains presented by gender

\begin{tabular}{|c|c|c|c|}
\hline \multirow{2}{*}{$\begin{array}{l}\text { Descriptive Statistics } \\
\text { mean } \pm S D *(\text { min-max }) \\
\text { median }(I Q R)\end{array}$} & \multicolumn{2}{|c|}{ Gender } & \multirow[b]{2}{*}{ p value } \\
\hline & male $\mathrm{N}=20$ & female $\mathrm{N}=11$ & \\
\hline \multirow[t]{2}{*}{ Physical } & $74.37 \pm 20.6$ & $71.97 \pm 14.1$ & ${ }^{b} \mathrm{p}=0.39 \mathrm{~ns}$ \\
\hline & $79.16(29.7)$ & $70.83(29.7)$ & \\
\hline \multirow[t]{2}{*}{ Vitality } & $68.33 \pm 18.6$ & $67.42 \pm 20.6$ & ${ }^{\mathrm{a}} \mathrm{p}=0.9 \mathrm{~ns}$ \\
\hline & $66.67-83.33$ & $66.67-75.0$ & \\
\hline \multirow[t]{2}{*}{ Emotion } & $72.33 \pm 22.2$ & $77.58 \pm 19.1$ & ${ }^{b} \mathrm{p}=0.55 \mathrm{~ns}$ \\
\hline & $73.33(45)$ & $86.67(26.7)$ & \\
\hline \multirow{2}{*}{ Eating } & $79.44 \pm 19.5$ & $80.81 \pm 22.3$ & ${ }^{b} \mathrm{p}=0.77 \mathrm{~ns}$ \\
\hline & $83.33(41.7)$ & $88.89(33.3)$ & \\
\hline \multirow{2}{*}{ Treatment Burden } & $59.44 \pm 22.9$ & $60.61 \pm 20.1$ & ${ }^{b} \mathrm{p}=0.98 \mathrm{~ns}$ \\
\hline & $61.11(41.7)$ & $66.67(33.3)$ & \\
\hline \multirow{2}{*}{ Health Perceptions } & $68.89 \pm 22.7$ & $72.73 \pm 18.8$ & ${ }^{\mathrm{a}} \mathrm{p}=0.64 \mathrm{~ns}$ \\
\hline & $11.11-100$ & $33.33-100$ & \\
\hline \multirow{2}{*}{ Social } & $50.56 \pm 8.2$ & $47.98 \pm 9.4$ & ${ }^{b} \mathrm{p}=0.43 \mathrm{~ns}$ \\
\hline & $51.0(5.6)$ & $50.0(11.1)$ & \\
\hline \multirow{2}{*}{ Body Image } & $73.89 \pm 26.1$ & $83.84 \pm 14.4$ & ${ }^{\mathrm{b}} \mathrm{p}=0.39 \mathrm{~ns}$ \\
\hline & $77.78(41.7)$ & $88.89(22.2)$ & \\
\hline \multirow{2}{*}{ Role } & $80.0 \pm 17.6$ & $76.51 \pm 20.3$ & ${ }^{b} \mathrm{p}=0.66 \mathrm{~ns}$ \\
\hline & $83.33(22.9)$ & $75.0(33.3)$ & \\
\hline \multirow{2}{*}{ Weight } & $80.0 \pm 29.4$ & $81.82 \pm 31.1$ & ${ }^{\mathrm{b}} \mathrm{p}=0.84 \mathrm{~ns}$ \\
\hline & $100(33.3)$ & $100(33.3)$ & \\
\hline \multirow{2}{*}{ Respiratory } & $71.94 \pm 16.4$ & $76.77 \pm 13.1$ & ${ }^{\mathrm{a}} \mathrm{p}=0.41 \mathrm{~ns}$ \\
\hline & $33.33-94.44$ & $55.56-94.44$ & \\
\hline \multirow{2}{*}{ Digest } & $87.78 \pm 17.2$ & $87.88 \pm 16.1$ & ${ }^{b} \mathrm{p}=0.97 \mathrm{~ns}$ \\
\hline & $100(22.2)$ & $100(22.2)$ & \\
\hline
\end{tabular}

${ }^{\mathrm{a}} \mathrm{p}$ (Student t-test for independent samples); ${ }_{\mathrm{b}}^{\mathrm{p}}$ (Mann-Whitney test); Standard deviation (SD), Interquartile range (IQR), Number of patients $(\mathrm{N})$, no statistical significance (ns)

At the time of the study, all analyzed patients received enzyme therapy and inhaled mucolytic. 29 patients $(93.55 \%)$ practiced physical therapy, 25 patients $(80.64 \%)$ received an antibiotic through inhalation, 22 patients $(70.97 \%)$ took vitamins, while 9 patients $(29.03 \%)$ received an antibiotic per os.

18 patients $(58.06 \%)$ received antibiotic treatment per os during the last year and 11 of them $(35.48 \%)$, due to exacerbation of the disease and worsening of the health condition, were hospitalized. High scores of 87.81, 80.64 and 79.93 were given for digestive condition, weight and eating condition, respectively.

The majority of the patients in this group believe that physical exercises have a positive impact on their health status (Table 6).

\section{Discussion}

The gender of the patients with $\mathrm{CF}$ at the age of 14 and older had no significant impact on their perception of HRQoL. The review of the literature data showed that Dębska et.al. (2003) also reported that there is no statistically significant difference between the genders. The only statistically significant difference in HRQoL parameters between women and men, was found for the
Physical parameter. However, the study conducted by Gee et al. (2003), refers differences in the assessment of HQoL between men and female.

Finding that males have a poorer body image than females is in line with previous research by Abbott et al. (2000). The available literature data show that some findings (Gee et al., 2003) are not in accordance with the study results obtained in this research.

In one study was referred that there is a differences in the clinical manifestation of CF's symptoms between black and white patients (Hamosh et al., 1998). Taking into account the fact that Macedonian and Albanian patients belong to the white race, differences in the manifestation of symptoms of $\mathrm{CF}$ are not expected. Reference this, the similar perception in HRQoL parameters (without statistical significance) between patients from these two ethnics was expected. The Macedonian patients reported higher score for emotion, eating, social activity, role and digestive condition, but there was no statistically significant difference. The physical condition, vitality, treatment burden, health perception body image, weight and respiratory function were scored not significantly higher by the patients with Albanian nationality in comparison with the patients from Macedonian nationality.

Maced. pharm. bull., 67 (1) 33 - 41 (2021) 
Table 4. Descriptive statistics for all analyzed HRQoL domains presented by ethnicity

\begin{tabular}{|c|c|c|c|c|c|}
\hline \multirow[b]{2}{*}{$\begin{array}{l}\text { Descriptive } \\
\text { Statistics } \\
\text { mean } \pm \text { SD } \\
*(\min -\max ) \\
\text { median(IQR) }\end{array}$} & \multicolumn{4}{|c|}{ Ethnicity } & \multirow[b]{2}{*}{$p$ value } \\
\hline & $\begin{array}{c}\text { ethnic } \\
\text { Macedonian } \\
\mathrm{N}=23\end{array}$ & $\begin{array}{l}\text { ethnic Albanian } \\
\mathrm{N}=5\end{array}$ & $\begin{array}{l}\text { other } \\
\mathrm{N}=1\end{array}$ & $\begin{array}{l}\text { prefer not to } \\
\text { answer } \\
\mathrm{N}=2\end{array}$ & \\
\hline Physical & $\begin{array}{l}72.83 \pm 19.9 \\
75.0(33.33)\end{array}$ & $\begin{array}{c}83.33 \pm 8.8 \\
83.333(16.7)\end{array}$ & 70.83 & $\begin{array}{c}58.33 \pm 5.9 \\
58.333 \\
\end{array}$ & ${ }^{b} \mathrm{p}=0.26 \mathrm{~ns}$ \\
\hline Vitality & $\begin{array}{l}68.84 \pm 19.2 \\
33.33-100\end{array}$ & $\begin{array}{c}70.0 \pm 19.2 \\
41.67-91.67\end{array}$ & 66.67 & $\begin{array}{l}54.17 \pm 29.5 \\
33.33-75.0\end{array}$ & ${ }^{\mathrm{a}} \mathrm{p}=0.93 \mathrm{~ns}$ \\
\hline Emotion & $\begin{array}{c}75.36 \pm 22.4 \\
80.0(40)\end{array}$ & $\begin{array}{c}68.0 \pm 19.7 \\
66.67(36.7)\end{array}$ & 86.67 & $\begin{array}{c}70.0 \pm 14.1 \\
70.0\end{array}$ & ${ }^{b} \mathrm{p}=0.5 \mathrm{~ns}$ \\
\hline Eating & $\begin{array}{l}81.64 \pm 19.7 \\
88.89(33.3)\end{array}$ & $\begin{array}{l}71.11 \pm 25.6 \\
77.78(50)\end{array}$ & 66.67 & $\begin{array}{c}88.89 \pm 15.7 \\
88.89\end{array}$ & ${ }^{\mathrm{b}} \mathrm{p}=0.31 \mathrm{~ns}$ \\
\hline $\begin{array}{l}\text { Treatment } \\
\text { Burden }\end{array}$ & $\begin{array}{l}58.45 \pm 22.1 \\
55.56(33.3)\end{array}$ & $\begin{array}{l}68.89 \pm 21.4 \\
77.78(33.3)\end{array}$ & 55.55 & $\begin{array}{c}55.56 \pm 31.4 \\
55.56\end{array}$ & ${ }^{b} \mathrm{p}=0.34 \mathrm{~ns}$ \\
\hline $\begin{array}{l}\text { Health } \\
\text { Perceptions }\end{array}$ & $\begin{array}{c}70.05 \pm 22.8 \\
11.11-100\end{array}$ & $\begin{array}{c}77.78 \pm 7.9 \\
66.67-88.89\end{array}$ & 66.67 & $\begin{array}{c}55.56 \pm 31.4 \\
33.33-77.78\end{array}$ & ${ }^{\mathrm{a}} \mathrm{p}=0.43 \mathrm{~ns}$ \\
\hline Social & $\begin{array}{c}50.24 \pm 8.3 \\
51(11.1)\end{array}$ & $\begin{array}{c}48.89 \pm 12.7 \\
50(19.4)\end{array}$ & 50.0 & $\begin{array}{c}44.44 \pm 0 \\
44.44\end{array}$ & ${ }^{b} \mathrm{p}=0.77 \mathrm{~ns}$ \\
\hline Body Image & $\begin{array}{l}74.39 \pm 24.0 \\
77.78(33.3)\end{array}$ & $\begin{array}{c}93.33 \pm 9.9 \\
100(16.7)\end{array}$ & 55.56 & $\begin{array}{c}83.33 \pm 23.6 \\
83.33\end{array}$ & $\mathrm{~b}=0.099 \mathrm{~ns}$ \\
\hline Role & $\begin{array}{l}79.71 \pm 20.7 \\
83.3333 .3()\end{array}$ & $\begin{array}{l}78.33 \pm 9.5 \\
75.0(16.7)\end{array}$ & 66.67 & $\begin{array}{c}75.0 \pm 11.8 \\
75.0\end{array}$ & ${ }^{\mathrm{b}} \mathrm{p}=0.89 \mathrm{~ns}$ \\
\hline Weight & $\begin{array}{c}78.26 \pm 32.7 \\
100(33.3)\end{array}$ & $\begin{array}{c}93.33 \pm 14.9 \\
100(16.7)\end{array}$ & 66.67 & $\begin{array}{c}83.33 \pm 23.6 \\
83.33\end{array}$ & ${ }^{b} \mathrm{p}=0.33 \mathrm{~ns}$ \\
\hline Respiratory & $\begin{array}{c}72.71 \pm 16.6 \\
33.33-94.44\end{array}$ & $\begin{array}{c}81.11 \pm 8.4 \\
72.22-88.89\end{array}$ & 77.78 & $\begin{array}{c}63.89 \pm 11.8 \\
55.56-72.22\end{array}$ & ${ }^{\mathrm{a}} \mathrm{p}=0.34 \mathrm{~ns}$ \\
\hline Digest & $\begin{array}{c}87.92 \pm 16.7 \\
100(22.2) \\
\end{array}$ & $\begin{array}{l}86.67 \pm 18.3 \\
88.89(27.8) \\
\end{array}$ & 100 & $\begin{array}{c}83.33 \pm 23.6 \\
83.33 \\
\end{array}$ & ${ }^{\mathrm{b}} \mathrm{p}=0.88 \mathrm{~ns}$ \\
\hline
\end{tabular}

${ }^{a} \mathrm{p}$ (Student t-test for independent samples); ${ }_{\mathrm{b}}^{\mathrm{p}}$ (Mann-Whitney test); Standard deviation (SD), Interquartile range (IQR), Number of patients $(\mathrm{N})$, no statistical significance (ns)

All seven patients with faculty degree, scored their digestive function with the highest score 100 . The lowest score for digestive function was obtained from patients with partially completed secondary education, with mean score 69.44 and mediana $66.67(p=0.012)$. Contrary to our finding, the education level of Polish and Greek patients had a significant influence for scoring of all HRQoL parameters (Borawska-Kowalczyk, 2015; Stofa et al., 2016). The reason why the education level of the patients with CF in R. of North Macedonia has no statistical impact on the HRQoL scoring could be explained by the fact that the Macedonian health care givers pay more attention on the patients with lower education.

In terms of frequency of practicing physical therapy, most of the answers were "at least twice" and "at least once a day". Half of the patients (48.39\%) answered that they are physically active for more than 30 minutes per day. Walking is the most common type of practiced physical activity by the patients with CF older than 14 years. Almost $71 \%$ of the patients practice walking and about $50 \%$ of patients used cycling. After a certain physical activity, $16.13 \%$ of the patients did not feel any change, $38.71 \%$ answered that the physical activity acts favorably on their condition (more easily breathed and less clogged), while $35.48 \%$ of the patients answered that they were coughing more secret. Patients who practiced physical therapy and physical activities reported high scores for physical conditions and body images. Previous reports also have indicated that regular physical activity had a positive impact on lung function in patients with $\mathrm{CF}$ (Schneiderman et al., 2014; Swisher and Erickson, 2008).

The lowest score for social activity (49.64) and treatment burden was reported within our previous study (Nakov et al., 2020). This fact could be explained by the negative impact of their medical condition in their selfperception and in the execution of their daily social activities.

The findings of the obtained high scores for digestive condition, weight and eating condition, are in a positive correlation with the fact that all patients included in this survey $(\mathrm{N}=31)$ took enzyme therapy. Most of surveyed patients $(\mathrm{N}=22)$ used vitamin therapy too. All surveyed patients used mucolytic through inhalation and majority of the patients $(80.64 \%)$ also used antibiotic through inhalation. These results are in a positive correlation with 
Table 5. Descriptive statistics for all analyzed HRQoL domains presented by level of completed education

\begin{tabular}{|c|c|c|c|c|c|}
\hline \multirow{2}{*}{$\begin{array}{l}\text { Descriptive } \\
\text { Statistics } \\
\text { mean } \pm \mathrm{SD} \\
*(\min -\mathrm{max}) \\
\text { median(IQR) }\end{array}$} & \multicolumn{4}{|c|}{ Level of completed education } & \multirow[b]{2}{*}{ p value } \\
\hline & $\begin{array}{l}\text { Primary school } \\
\qquad N=9\end{array}$ & $\begin{array}{c}\text { Part of } \\
\text { secondary } \\
\text { school } \\
\mathrm{N}=4\end{array}$ & $\begin{array}{c}\text { Secondary } \\
\text { school } \\
\mathrm{N}=11\end{array}$ & $\begin{array}{l}\text { Faculty } \\
\mathrm{N}=7\end{array}$ & \\
\hline Physical & $\begin{array}{l}75.93 \pm 23.1 \\
87.50(33.3)\end{array}$ & $\begin{array}{l}78.12 \pm 16.8 \\
83.33(30.2) \\
\end{array}$ & $\begin{array}{l}76.14 \pm 15.5 \\
79.17(20.8) \\
\end{array}$ & $\begin{array}{l}63.69 \pm 16.8 \\
70.83(16.7) \\
\end{array}$ & $\mathrm{b}=0.35 \mathrm{~ns}$ \\
\hline Vitality & $\begin{array}{l}70.37 \pm 21.7 \\
33.33-100 \\
\end{array}$ & $\begin{array}{c}72.92 \pm 29.93 \\
33.33-100 \\
\end{array}$ & $\begin{array}{c}68.94 \pm 14.9 \\
41.7-91.7 \\
\end{array}$ & $\begin{array}{c}60.71 \pm 16.5 \\
33.33-75\end{array}$ & ${ }^{\mathrm{a}} \mathrm{p}=0.71 \mathrm{~ns}$ \\
\hline Emotion & $\begin{array}{l}65.92 \pm 19.8 \\
73.33(33.3) \\
\end{array}$ & $\begin{array}{l}76.67 \pm 20.0 \\
73.33(36.7) \\
\end{array}$ & $\begin{array}{c}78.18 \pm 23.7 \\
86.67(40) \\
\end{array}$ & $\begin{array}{c}77.14 \pm 19.9 \\
80.0(40) \\
\end{array}$ & ${ }^{b} \mathrm{p}=0.45 \mathrm{~ns}$ \\
\hline Eating & $\begin{array}{l}75.31 \pm 20.6 \\
66.67(38.9) \\
\end{array}$ & $\begin{array}{l}83.33 \pm 21.9 \\
88.88(38.9)\end{array}$ & $\begin{array}{l}83.84 \pm 21.9 \\
88.89(33.3)\end{array}$ & $\begin{array}{l}77.78 \pm 19.2 \\
77.78(44.4) \\
\end{array}$ & ${ }^{b} \mathrm{p}=0.79 \mathrm{~ns}$ \\
\hline Treatment Burden & $\begin{array}{l}70.37 \pm 16.7 \\
77.78(27.8)\end{array}$ & $\begin{array}{l}55.56 \pm 20.3 \\
55.56(38.9)\end{array}$ & $\begin{array}{l}59.59 \pm 23.9 \\
55.56(44.4)\end{array}$ & $\begin{array}{l}49.21 \pm 22.1 \\
44.44(44.4)\end{array}$ & ${ }^{b} \mathrm{p}=0.27 \mathrm{~ns}$ \\
\hline $\begin{array}{l}\text { Health } \\
\text { Perceptions }\end{array}$ & $\begin{array}{l}74.07 \pm 16.7 \\
44.44-100 \\
\end{array}$ & $\begin{array}{c}66.67 \pm 28.7 \\
33.33-100 \\
\end{array}$ & $\begin{array}{l}74.75 \pm 15.8 \\
44.44-100\end{array}$ & $\begin{array}{c}60.32 \pm 29.3 \\
11.11-100 \\
\end{array}$ & ${ }^{\mathrm{a}} \mathrm{p}=0.5 \mathrm{~ns}$ \\
\hline Social & $\begin{array}{c}48.15 \pm 11.1 \\
50.0(19.4) \\
\end{array}$ & $\begin{array}{l}44.44 \pm 12.0 \\
47.22(22.2) \\
\end{array}$ & $\begin{array}{l}53.54 \pm 4.5 \\
55.56(5.6) \\
\end{array}$ & $\begin{array}{c}48.41 \pm 6.9 \\
50.0(5.6) \\
\end{array}$ & ${ }^{b} \mathrm{p}=0.24 \mathrm{~ns}$ \\
\hline Body Image & $\begin{array}{l}82.72 \pm 17.7 \\
88.89(33.3)\end{array}$ & $\begin{array}{l}63.89 \pm 18.9 \\
61.11(36.1) \\
\end{array}$ & $\begin{array}{l}81.82 \pm 15.1 \\
88.89(11.1)\end{array}$ & $\begin{array}{l}71.43 \pm 37.3 \\
88.89(44.4)\end{array}$ & ${ }^{b} \mathrm{p}=0.44 \mathrm{~ns}$ \\
\hline Role & $\begin{array}{l}78.71 \pm 21.3 \\
83.33(37.5) \\
\end{array}$ & $\begin{array}{c}79.17 \pm 14.4 \\
75.0(25) \\
\end{array}$ & $\begin{array}{l}79.54 \pm 21.8 \\
83.33(33.3) \\
\end{array}$ & $\begin{array}{c}77.38 \pm 13.4 \\
83.33(25) \\
\end{array}$ & ${ }^{b} \mathrm{p}=0.92 \mathrm{~ns}$ \\
\hline Weight & $\begin{array}{l}77.78 \pm 33.3 \\
100(33.3)\end{array}$ & $\begin{array}{c}75.0 \pm 31.9 \\
83.33(58.3)\end{array}$ & $\begin{array}{c}87.88 \pm 22.5 \\
100(33.3)\end{array}$ & $\begin{array}{c}76.19 \pm 37.1 \\
100(33.3)\end{array}$ & ${ }^{\mathrm{b}} \mathrm{p}=0.79 \mathrm{~ns}$ \\
\hline Respiratory & $\begin{array}{l}75.31 \pm 15.9 \\
50.0-94.44\end{array}$ & $\begin{array}{c}63.89 \pm 13.2 \\
55.56-83.33\end{array}$ & $\begin{array}{l}78.28 \pm 12.5 \\
50.0-94.44\end{array}$ & $\begin{array}{l}69.84 \pm 18.7 \\
33.33-94.4\end{array}$ & ${ }^{\mathrm{a}} \mathrm{p}=0.38 \mathrm{~ns}$ \\
\hline Digest & $\begin{array}{l}83.95 \pm 19.3 \\
88.89(27.8)\end{array}$ & $\begin{array}{c}69.44 \pm 13.9 \\
66.67(25)\end{array}$ & $\begin{array}{c}89.89 \pm 14.4 \\
100(22.2)\end{array}$ & $\begin{array}{c}100 \pm 0 \\
100\end{array}$ & ${ }^{\mathrm{b}} \mathrm{p}=0.012 \mathrm{sig}$ \\
\hline
\end{tabular}

${ }^{a} \mathrm{p}$ (Analysis of Variance; post hoc Tukey test), ${ }^{\mathrm{b}} \mathrm{p}$ (Kruskal-Wallis ANOVA; post hoc Mann-Whitney test), Standard deviation (SD), Interquartile range (IQR), Number of patients $(\mathrm{N})$, no statistical significance (ns)

Table 6. Impact of physical exercises of patients' health

\begin{tabular}{lc}
\hline \hline \multicolumn{2}{c}{ Do you think that physical exercises and sports are important for your health? } \\
\hline Yes, I feel better & $22(70.97 \%)$ \\
Rarely exercise & $8(25.81 \%)$ \\
I do not have a time to practice & 0 \\
I feel tired & $1(3.23 \%)$ \\
\hline
\end{tabular}

the fact that the respiratory function is scored with relatively high score of 73.65 . The benefit of the enzyme, antibiotic and physical therapy on the digestive condition and the respiratory function was also observed for pediatric CF patients in R. North Macedonia (Nakov et al., 2019).

\section{Conclusion}

In conclusion, the HRQoL study of teen/adult patients with $\mathrm{CF}$ in the $\mathrm{R}$. of North Macedonia was conducted for the first time.
The findings of our study revealed that the nationality (Macedonian or Albanian) and the gender have no statistically significant impact on the perception for HRQoL.

The highest score for digestive condition in all analyzed subjects was in positive correlation with the fact that all patients continuously used enzyme therapy, thereby indicating the important role of this kind of therapy in patients with $\mathrm{CF}$. This study also revealed that, in contrary to other countries, the level of education in teen/adult patients with CF in R. of North Macedonia has no statistical impact on the HRQoL scoring on the perception of their digestive function. The obtained results 
could be explained by the fact that the Macedonian health care givers pay more attention on the patients with lower education.

Patients who practiced physical therapy and different physical activities (waking, cycling) reported relatively high scores for physical conditions and body images. This finding underline the importance of the physical activity and the need of encouraging the patients with $\mathrm{CF}$ to practice physical activity more often.

\section{Acknowledgments}

We would like to express our sincere gratitude to the developers of the Cystic Fibrosis Questionnaire (CFQ) / Cystic Fibrosis Questionnaire Revised (CFQ-R): B Henry, P Aussage, C Grosskopf, JM Goehrs, R Launois and the French CFQOL Study Group and to the developer of the English CFQ / CFQ-R: Dr. Alexandra Quittner Department of Psychology, University of Miami- Coral Gables, FL 33124-0751 Phone 305-284-2814, Fax: 305284-3402, E-mail:aquittner@miami.edu.

\section{References}

Abbott, J., Conway, S., Etherington, C., Fitzjohn, J., Gee, L., Morton, A., Musson, H., Webb, A.K., 2000. Perceived body image and eating behavior in young adults with cystic fibrosis and their healthy peers. Journal of Behavioral Medicine 23(6), 501-517. Available at: https://doi.org/10.1023/a:1005532602084.

Association for cystic fibrosis. Available at: www.cf.mk (Last accessed: 30.03.2021).

Bobadilla, J.L., Macek, M., Fine, J.P., Farrell, P.M. 2002. Cystic fibrosis: A worldwide analysis of CFTR mutation. Correlation with incidence data and application to screening. Human Mutation 19, 575-606. Available at: https//doi.org/10.1002/humu.10041.

Borawska-Kowalczyk, U., Sands, D., 2015. Determinants of health-related quality of life in polish patients with CF adolescents' and parents' perspectives. Developmental Period Medicine 19, 127-136.

Cystic fibrosis foundation. Available at: https://www.cff.org/What-is-CF/About-Cystic-Fibrosis (Last accessed: 03.04.2021).

Dębska, G., 2003. Jakość życia chorych na mukowiscydozę. Acta Pneumonologica et Allergologica Pediatrica 6(3), 3942.

Elborn, J.S., Shale, D.J., Briton, J.R., 1991. Cystic fibrosis current survival and population estimates to year 2000 . Thorax 46, 881-885. Available at: https://doi.org/10.1136/thx.46.12.881.

European Cystic Fibrosis Society Patient Registry. Available at: https://www.ecfs.eu/projects/ecfs-patient-registry/project (Last accessed: 30.03.2021).

EUnetHTA Joint Action 2, Work Package 8. HTA Core Model (B) version 3.0 (Pdf), 2016. Available at: www.htacoremodel.info/BrowseModel.aspx (Last accessed: 25.03.2021).
EUnetHTA - European network for Health Technology Assessment, 2013. Guideline - Endpoints used for relative effectiveness assessment of pharmaceuticals, HEALTHRELATED QUALITY OF LIFE and UTILITY MEASURES. Available at:

http://www.eunethta.eu/sites/5026.fedimbo.belgium.be/files /Health-related\%20quality\%20of\%20life.pdf (Last accessed 22.03.2021).

European Medicines Agency, 2006. Reflection paper on the regulatory guidance for the use of health-related quality of life (HRQL) measures in the evaluation of medicinal products. London: EMA,

EMEA/CHMP/EWP/139391/2004. Available at:

http://www.ispor.org/workpaper/emea-hrql-guidance.pdf 5 (Last accessed: 25.03.2021).

Food and Drug Administration, 2009. Guidance for Industry. Patient-Reported Outcome Measures: Use in Medical Product Development to Support Labeling Claims. Available at:

https://www.fda.gov/downloads/drugs/guidances/ucm1932 82.pdf 2009 (Last accessed: 25.03.2021).

FitzSimmons, SC., 1993. The changing epidemiology of cystic fibrosis. The Journal of Pediatrics 122, 1-9. Available at: https://doi.org/10.1016/s0022-3476(05)83478-x.

Gee, L., Abbott, J., Conway, S., 2003. Quality of life in cystic fibrosis: the impact of gender, general health perceptions and disease severity. Journal of Cystic Fibrosis 2, 206-213. Available at: https://doi.org/10.1016/S1569-1993(03)00093-6.

Goodman, C.S., 1998. Healthcare technology assessment: methods, framework, and role in policy making. The American Journal of Managed Care, Spec No. SP200-14, quiz SP215.

Hamosh, A., FitzSimmons, S.C., Macek, M., Knowles, M.R., Rosenstein, B.J., Cutting, GR., 1998. Comparison of the clinical manifestations of cystic fibrosis in black and white patients. Journal of Pediatrics 132(2), 255-259. Available at: https://doi.org/10.1016/s0022-3476(98)70441-x.

Henry, B., Aussage, P., Grosskopf, C., Goehrs, J.M., Launois, R., \& the French CFQOL. 2017. Study Group: Cystic Fibrosis Questionnaire (CFQ); Cystic Fibrosis Questionnaire Revised (CFQ-R); Dr. Alexandra Quittner Department of Psychology University of Miami: English CFQ and CFQ-R.

Jackowski, D., Guyatt, G., 2003. A Guide to Health Measurement. Clinical Orthopaedics and Related Research 413, 80-89. Available at: https://doi.org/10.1097/01.blo.0000079771.06654.13.

Kerem, E., Conway, S., Elborn, S., Heijerman, H., Consensus Committee, 2005. Standards of care for patients with cystic fibrosis: a European consensus. Journal of Cystic Fibrosis 4(1), 7-26. Available at: https://doi.org/10.1016/j.jcf.2004.12.002.

Lewis, P.A., 2007. The epidemiology of cystic fibrosis, in: Hodson, M., Geddes, D., Bush, A. (Eds.), Cystic fibrosis 3rd edition. Hodder Education Publisher, London, United Kingdom.

Naceva Fushtikj, S., 2012. From basic defect to disease. Skopje: Sfera print and marketing.

Nakov, Z., Naceva Fushtikj, S., Tonikj-Ribarska, J., Trajkovikj Jolevska, S., 2019. Health-related quality of life of Macedonian families experiencing cystic fibrosis in 
paediatric practice. Folia Medica 61(2), 213-222.

Nakov, Z., Naceva Fushtikj, S., Acevski, S., Tonikj-Ribarska, J., Trajkovikj Jolevska, S., 2020. Social aspect as a part of HRQoL in patients with cystic fibrosis in Republic of North Macedonia. Macedonian Pharmaceutical Bulletin 66(Supl 1), 167-168. Available at: https://doi.org/10.33320/maced.pharm.bull.2020.66.03.08 3 .

Schneiderman, J.E., Wilkes, D.L., Atenafu E.G., Nguyen, T., Wells, G.D., Alarie, N., Tullis, E., Lands, L.C., Coates, A.L., Corey, M., Ratjen, F., 2014. Longitudinal relationship between physical activity and lung health in patients with cystic fibrosis. European Respiratory Journal 43, 817-823. Available at: https://doi.org/10.1183/09031936.00055513.

SPSS statistical software. International Business Machines Corp. Armonk, New York.

Stofa, M., Xanthos, T., Ekmektzoglou, K., Chalkias, A.,
Barouxis, D., Pantazopoulos, I., Iacovidou, N., 2016. Quality of life in adults with cystic fibrosis: The Greek experience. Pneumonologia I Alergologia Polska 84(4), 205-211.

Swisher, A.K., Erickson, M., 2008. Perceptions of Physical Activity in a Group of Adolescents with Cystic Fibrosis. Cardiopulmonary Physical Therapy Journal 19(4), 107113.

Tsui, LC., Buchwald, M., 1991. Biochemical and molecular genetics of cystic fibrosis. Advances in Human Genetics 20, 153-166. Available at: https://doi.org/10.1007/978-14684-5958-6_4.

Zemanick, T., Harris, K., Conway, S., Konstan, M.W., Marshall, B., Quittnere, A., 2010. Measuring and improving respiratory outcomes in cystic fibrosis lung disease: Opportunities and challenges to therapy. Journal of Cystic Fibrosis 9, 1-16. Available at: https://doi.org/10.1016/j.jcf.2009.09.003.

\title{
Испитување на квалитет на живот во однос на здравјето кај адолесценти/возрасни пациенти со цистична фиброза во Република Северна Македонија
}

\author{
Зоран Наков ${ }^{1 *}$, Стевче Ацевски ${ }^{2}$, Валентина Велкоска ${ }^{3}$, Стојка Нацева Фустиќ $^{4}$, \\ Наталија Наков ${ }^{5}$, Јасмина Тониќ Рибарска ${ }^{5}$, Сузана Трајковиќ Јолевска
}

\author{
${ }^{1}$ Ново Нордиск Фарма ДООЕЛ, бул. Октомвриска Револуичија 18, \\ 1000 Скопје, Р. Северна Македонија \\ ${ }^{2}$ Рош Македонија ДООЕЛ, ул. Кирил и Методиј 7, \\ 1000 Скопје, Р. Северна Македонија \\ ${ }^{3}$ Факултет за медииински науки, Универзитет „Гоце Делчев” Штип, \\ ул. Љубен Иванов 25, 2000 Штип, Р. Северна Македонија \\ ${ }^{4}$ Универзитетска клиника за детски болести, Универзитет „Св. Кирил и Методиј”, \\ ул. Мајка Тереза 47, 1000 Скопје, Р. Северна Македонија \\ 5 Фармацевтски факултет, Универзитет „, Св. Кирил и Методиј”, \\ ул. Мајка Тереза 47, 1000 Скопје, Р. Северна Македонија
}

Клучни зборови: цистична фиброза, квалитет на живот во однос на здравјето, дигестивна функција, дневни активности

Во ова студија се презентирани резултати за квалитетот на живот во однос на здравјето кај адолесценти/возрасни пациенти со цистична фиброза во Република Северна Македонија. Ваков тип на истражување кај нас е спроведен за прв пат. Примарна цел на истражувањето беше да се направи процена на квалитетот на живот во однос на здравјето кај оваа група пациенти а секундарна цел беше овие добиени резултати да се поврзат со моментална терапија која ја добиваат пациентите вклучени во ова истражување.

Во истражувањето беа вклучени вкупно 31 пациент, со користење на ревидираниот прашалник за испитување на квалитет на живот во однос на здравјето за пациенти со цистична фиброза и дополнителни прашања за тековниот медицински третман на оваа група испитаници. 
Дигестивната функција беше оценета со највисока оцена од страна на сите пациенти а најниска оцена беше добиена за нивните дневни / социјални активности. Полот на пациентите, нивната национална припадност и степенот на нивното образование немаа статистичко значење во нивната перцепција за квалитетот на живот во однос на здравјето.

Највисоката оцена добиена за дигестивната состојба е во позитивна корелација со податокот дека сите испитаници континуирано користат ензимска терапија. Пациентите кои се на физикална терапија и практикуваат физичка активност, со повисока оцена ја имаат оценето нивната физичка кондиција. Со овој податок се наметнува заклучокот дека оваа група на пациенти треба да бидат поттикнати за редовна физичка активност, на дневна база.

Најниските оцени за нивните дневни активности и ограничувањата на третманот се потврда на фактот дека оваа здравствена состојба има негативно влијаните во личната перцепција на овие пациенти и во спроведувањето на нивните дневни активности. 
